\title{
Potential for Ribes Cultivation in North America
}

Adam Dale

ADDITIONAL INDEX WORDS. black currant, red currant, gooseberry, jostaberry, $R$ i bes ni grum, $R$ i bes rubrum, $R$ i bes grossularia, R ibesnidigrolaria

Summary. Fruit from black, red and white currants, and gooseberries ( $R$ ibes L.) were grown commercially in $\mathrm{N}$ orth America at the beginning of the $20^{\text {th }}$ C entury. $\mathrm{H}$ owever, when white pine blister rust (WPBR)

(Cronartium ribicola J. C. Fisch.) was introduced into the new world, their cultivation was discontinued.

About $825,000 \mathrm{t}(908,000$ tons) of $R$ ibes fruit are produced worldwide, almost entirely in $E$ urope. The fruit is high in vitamin $C$, and is used to produce juice, and many other products. N ow a wide range of imported $R$ ibes products is available particularly in C anada, and the pick-your-own (PYO) market is increasing. T wo diseases, powdery mildew [Spaerotheca morsuvae (Schwein.) Berk. \& C urt.] and WPBR, are the major problems encountered by growers. Fortunately, many new cultivars are resistant to these two diseases. Commercial acreage of $R$ ibesin N orth America is located where the growing day degrees above $5^{\circ} \mathrm{C}\left(41^{\circ} \mathrm{F}\right)$, and the annual chilling hours are at least 1200. Initially, the R ibes industry will develop as PYO and for farm markets. But for a large industry to develop, juice products will needed. 0 ur costs of production figures indicate that about 850 Canadian dollars (\$CDN) per $1.0 \mathrm{t}$ (1.1 tons) of fruit will be required to break even.

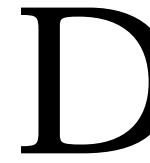

ifferent $\mathrm{R}$ ibes fruit are popular in Europe, but despite interest from grow ers, very few acres are cultivated in N orth America. The main reason for this is that $R$ ibes, especially black currant ( $R$ ibesnigrum $L$.) is an alternate host for WPBR. Because forest products are a major industry in N orth America, $\mathrm{R}$ ibes plants were declared to be a pest and destroyed to control the disease in pines (PinusL.). H owever, now that many areas are devoid of commercial fiveneedle pine plantations and the laws that limit fruit production have been repealed, growers have renewed interest in cultivating black currants.

To examine the potential of $\mathrm{R}$ ibes in $\mathrm{N}$ orth America, we need to define the present situation, and then discuss the future potential. Barney (1996) discussed this topic, but this paper will update the current situation and explore the potential for cultivation in greater detail.

\section{The present}

R i bes USED COMMERcially. The $R$ ibes used commercially are found in three subgenera: R ibes, R ibesia and Grossularia. Black currants (subgenus: $\mathrm{R}$ ibes) are the most widely grown commercially, and the most economically important species in this subgenus is R. nigrum. M ost red and white currants (subgenus: R ibesa) grown commercially are related to $R$. sativum Syme, $R$. petraeum Wulf., or R . rubrum L. The gooseberries (subgenus Grossularia) are mostly hybrids between the european gooseberry $R$. grossularia L. (R. uva-crispa L.) and the american gooseberry, R . hirtellum M ichx. (Brennan, 1996).

U niversity of G uelph, D epartment of Plant Agriculture, Box 587, 1283 Blueline Road, Simcoe,O ntario N 3Y 4N 5, Canada.

The cost of publishing this paper was defrayed in part by the payment of page charges. U nder postal regulations, this paper therefore must be hereby marked adverti sement solely to indicate this fact. 
T able I. W orld production of currants, averaged from 1996-98 (FAO, 1999). .

\begin{tabular}{lc}
\hline Country & Production (t) \\
\hline Europe (25 countries) & 648,695 \\
Russian Federation & 190,000 \\
Poland & 176,086 \\
G ermany & 144,843 \\
Rest of the world & 1,793 \\
N ew Zealand & 1,867 \\
Australia & 866 \\
N orth Americay & 60 \\
Total & 650,488 \\
\hline
\end{tabular}

$\mathrm{z} 1 \mathrm{t}=1.1$ tons.

yN on-FAO estimate.

T able 2. World production of gooseberries, averaged from 1996-98 (FAO, 1999). ${ }^{2}$

$\mathrm{z} 1 \mathrm{t}=1.1$ tons.

Recently, jostaberries ( $R$. nidigrolaria Bauer), black currant $x$ go oseberry hybrids havebeen released, but so far these have made little impact commercially (Bauer, 1986).

WorLd PRODUCTION. World production of $\mathrm{Ribes}$ is reported to be about 825,000 t (T ables 1 and 2), 99\% of which comes from Europe (Food and Agricultural O rganization, 1999). $M$ ost of the tonnage for trade is black currants of which about two-thirds, come from Poland (Andrews, 1999). Although Russia and Germany producelarge quantities, most of these are

$\mathrm{N}$ orth American production is very small and largely unrecorded.

\begin{tabular}{lc}
\hline Country & Production (t) \\
\hline Europe (12 countries) & 174,484 \\
G ermany & 74,344 \\
Poland & 38,705 \\
Russian Federation & 34,333 \\
Rest of the world & \\
N ew Zealand & 27 \\
Total & 174,511 \\
\hline
\end{tabular}
consumed locally.

Black currants are more popular in Canada and the northern states and red currants and gooseberries are of more interest further south. Present estimates of production would suggest that several hundred acres might be grown throughout $\mathrm{N}$ orth America, mostly in O ntario, British Columbia, $O$ regon and Washington.

Products. Ribes fruit are used mainly asprocessed products, although red and white currants and gooseberries are edible as a fresh dessert. Processed products include juice, jams and preserves, pie fillings, dessert toppings, yogurt, ice cream, mineral waters, teas, liqueurs, candies, perfumes, and the seeds can potentially be used to produce gamma-linolenic acid.

About $80 \%$ of the black currant crop is used to produce juice, which is extremely high in vitamin C (ascorbic acid). I ts concentration in fruit can be four timeshigher than in oranges [ $\mathrm{Cit}$ russinensis(L.) 0 sbeck] and 50 times higher than in apples ( $M$ alusdomestica Borkh). (Table 3). D espite the lack of Canadian-grown fruit, various black currant products are available in the supermarkets and speciality stores throughout $\mathrm{C}$ anada. So far this year, I have found a number of products locally available. These include Crancurrant from $O$ cean Spray (L akevilleM iddleboro, Mass.) and own label brands, Ribena juice concentrate bottled in O ntario, jams, tea bags, mousse torte, cookies, black currant liqueur (Ontario produced and imported), candies, and throat lozenges. All this indicates that a demand for the product exists but that a major marketing effort would be needed to increase the volumes.

\section{The potential in North America}

Area of potential cultivation. $\mathrm{N}$ orth America is one of the main

Table 3. Nutrient composition of selected fruits from $100 \mathrm{~g}$ ( $3.5 \mathrm{oz}$ ) edible portion (U SD A, 1982). ${ }^{2}$

\begin{tabular}{lcccr}
\hline Nutrient & $\begin{array}{c}\text { B lack } \\
\text { currants }\end{array}$ & $\begin{array}{c}\text { Red } \\
\text { currants }\end{array}$ & Oranges & Apples \\
\hline Water (\%) & 82.0 & 84.0 & 87.0 & 84.0 \\
Food energy (kJ) & 266.0 & 234.0 & 197.0 & 237.0 \\
Protein (g) & 1.4 & 1.4 & 0.9 & 0.1 \\
Total lipid (g) & 0.4 & 0.2 & 0.1 & 0.3 \\
Total carbohydrates (g) & 15.4 & 13.8 & 11.8 & 14.9 \\
Ascorbic acid (mg) & 181.0 & 41.0 & 53.0 & 4.0 \\
\hline z1.0 kJ =239 calories, $1000 \mathrm{mg} \mathrm{=1} \mathrm{g=0.035} \mathrm{oz.}$ & & &
\end{tabular}

geographical centres of diversity for Ribes (Brennan, 1996) and various species are found throughout most of the continent. Various species are native from northern Canada ( $\mathrm{H}$ udson Bay) and Alaska, south to California, $\mathrm{N}$ ew Mexico, Arkansas and North Carolina(Rehder, 1937). For example, the wild black currant, $R$. americanum $\mathrm{M}$ ill., grows from $\mathrm{N}$ ew Brunswick to Alberta and south to $\mathrm{N}$ ew $\mathrm{M}$ exico and D elaware and the wild gooseberry, $R$. hirtellum, growsFrom $N$ ewfoundland to $M$ anitoba south to $M$ innesota and West $V$ irginia ( So per and $\mathrm{H}$ eimburger 1982). Thus, R ibes can be cultivated throughout the range of the native species provided that adequate moisture is supplied (Barney, 1996).

A nother way of looking at the potential areas of cultivation is to find parameters that define northern and southern limits. $\mathrm{H}$ owever, individual microclimates exist beyond the edges of the general limits of cultivation. At theselocations, adapted cultivars could be grown.

The length of the growing season and the maximum midwinter temperature could define the northern limit. At Simcoe, Ontario, currants and gooseberries usually produce ripe fruit in the middle of July and the 30 year average growing day degrees above 5 ${ }^{\circ} \mathrm{C}\left(41^{\circ} \mathrm{F}\right)$ from January to July are 1221 (Environment Canada, 1982), which would suggest that 1200 would beareasonablenorthern limit for $\mathrm{R}$ ibes. Also, fruit buds in cultivated Ribes deep super-cool so that their maximum winter hardiness is $-40{ }^{\circ} \mathrm{C}(-40$ $\left.{ }^{\circ} \mathrm{F}\right)$. $\mathrm{H}$ owever, some species have been reported to be hardy to as low as -60 ${ }^{\circ} \mathrm{C}\left(-70^{\circ} \mathrm{F}\right)$, and Russian scientists havemadeconsiderableeffortsto breed winter hardy varieties (Keep, 1975).

The number of chilling hours and the summer temperatures can define the southern limit. M odern R ibesvarieties need between 800 to $1500 \mathrm{HR}$ below $7{ }^{\circ} \mathrm{C}\left(45^{\circ} \mathrm{F}\right)$ to remove bud dormancy or physiological rest (H imelrick and Galletta, 1990). So a compromise of about $1200 \mathrm{HR}$ would set a reasonable southern limit. All provinces of $C$ anada and all states of the U .S. except Florida, $\mathrm{H}$ awaii, and L ouisiana have at least so me areas that exceed this level (Swartz and Gray, 1981). $\mathrm{H}$ armat et al. (1990) indicated that leaves of many varieties are damaged at air temperatures above $30^{\circ} \mathrm{C}$ $\left(86^{\circ} \mathrm{F}\right)$. O ur experience with other 


\begin{tabular}{|c|c|c|}
\hline $\begin{array}{l}\text { Input or } \\
\text { output }\end{array}$ & $\begin{array}{l}\text { Q uantity } \\
\text { used }\end{array}$ & $\begin{array}{c}\text { Cost or price/ } \\
\text { unit used } \\
\text { (\$C anadian) }\end{array}$ \\
\hline \multicolumn{3}{|l|}{ Inputs } \\
\hline \multicolumn{3}{|l|}{ Establishment } \\
\hline Plants & 5436 plants/ ha & $0.73, \$ /$ plant \\
\hline Planting labor & $20 h \cdot h a^{-1}$ & $15.00, \$ / \mathrm{h}$ \\
\hline L and preparation & & $247.00, \$ /$ ha \\
\hline Fumigation/ row & & $310.00, \$ /$ ha \\
\hline Black plastic & & $495.00, \$ /$ ha \\
\hline I rrigation equipment & & $310.00, \$ /$ ha \\
\hline \multicolumn{3}{|l|}{ Annual } \\
\hline Fertilizer $^{y}$ & $224 \mathrm{~kg} / \mathrm{ha} /$ year & $2.21, \$ / \mathrm{kg}$ \\
\hline I rrigation & $1000 \mathrm{~kL} / \mathrm{ha} /$ year & $0.264, \$ / \mathrm{kL}$ \\
\hline Pruning labor & $90 \mathrm{~h} / \mathrm{ha} /$ year & $15.00, \$ / \mathrm{h}$ \\
\hline H erbicides (materials plus application) & & $148.00, \$ / \mathrm{ha} /$ year \\
\hline Insecticides and fungicides ${ }^{x}$ & & $0.00, \$ /$ hal year \\
\hline Land & & $247.00, \$ /$ hal year \\
\hline \multicolumn{3}{|l|}{$\mathrm{H}$ arvest } \\
\hline O ther labor & $49 \mathrm{~h} / \mathrm{ha}$ & $15.00, \$ / \mathrm{h}$ \\
\hline \multicolumn{3}{|l|}{$\mathrm{O}$ utputs and revenue } \\
\hline Yield & $1 \mathrm{~kg} / \mathrm{plant} / \mathrm{year}$ & $4.40, \$ / \mathrm{kg}$ \\
\hline \multicolumn{3}{|l|}{ Time related factors } \\
\hline Life expectancy of plants (years) & & 20 \\
\hline Discount rate (\%) & & 10.00 \\
\hline First year production adjustment (\%) & & 0.00 \\
\hline Second year production adjustment (\%) & & 50.00 \\
\hline \multicolumn{3}{|l|}{ Results } \\
\hline Present value of annual cash flow ( $\$ /$ ha) & $\$ 127,071.43$ & \\
\hline I nternal rate of return (\%) & 104.98 & \\
\hline Benefit cost ratio & 25.83 & \\
\hline
\end{tabular}

z1 ha $=2.47$ acres, $1 \mathrm{~kg}=2.2 \mathrm{lb}, 1 \mathrm{~kL}=264 \mathrm{gal}$.

$\mathrm{yM}$ inimum composition $=20 \mathrm{~N}-20 \mathrm{P}-20 \mathrm{~K}$.

XVarieties planted are resistant to powdery mildew.

small fruit has been that these symptoms are exacerbated by wind and drought and can be alleviated by shelter and supplemental irrigation.

MARKet. Becausemost R ibesproducts are processed in some form, the markets will betied to those products. At present, PYO has considerable interest in Canada and this market is growing steadily. Eventually surplus fruit from PYO operationswill befound in local farm markets. However, this market is relatively small and I estimate that it would become saturated if 50 states and provinces had on average 40 ha (100 acres) of PYO Ribes, i.e., 2,000 ha(5,000 acres) continent-wide.

The major market for expansion would be for juice products. The juice market in the U nited States is presently worth about \$CD N 8.72 billion (Industry Canada, 1999), so a $1 \%$ market penetration would be worth \$CDN 87 million. The amount of acres required for this is extremely difficult to estimate. The most reliable figure I could find was that $100 \mathrm{t}$ ( 110 tons) of fruit, [20 ha (50 acres) at 5 $\mathrm{t} \cdot \mathrm{ha} \mathrm{a}^{-1}$ (2.2 ton/ acre)] yields about $9450 \mathrm{~L}(2,500 \mathrm{gal})$ of juice concentrate (10:1) (J. Sheffrin, personnel communication).

O ther untapped markets exist. $E$ vidence from many states and provinces suggests that the market for dessert fruit winesisexpanding. Thiscould become the next marketing blitz for the alcohol industry and just where $R$ ibescrops may fit into this industry is unknown. H owever, already in $\mathrm{O}$ ntario, Southbrook Farms is winning prizes in international competitions for Cassis.

Provided that suitablemarketscan be developed, North America could support a $\mathrm{R}$ ibesindustry similar in size to that of Poland. Poland presently produces about 200,000 t $(220,000$ tons) of currants and gooseberries, which would represent 28 to 40 thousand ha (70 to 100 thousand acres).

Costs of PRoduction. Becausefew acres of $\mathrm{R}$ ibes are grown in North America, accurate costs of production havenot been published. M ycolleague, G lenn Fox, D ept. of A gricultural E conomics and Business, U niversity of Guelph, and myself have been able to construct two spreadsheetsto estimate the costs of production of black currants for the juice market and for PYO (Tables 4-7). We have used a yield of $1 \mathrm{~kg}(2.2 \mathrm{lb})$ per plant $\left(5 \mathrm{t} \cdot \mathrm{ha}^{-1}\right)$ as this has been attained regularly in trials at Simcoe and appears to be the average in E urope. Wealso used 20 years as the life of the planting because reversion virus is not present in $\mathrm{N}$ orth America.

Plantations of PYO Black currants can be very profitable as indicated by the present value of the annual cash flow of \$CD N 127,071/ ha ( $\$ C D N 51,426 /$ acre) and the benefit cost ratio of 25.83 (Tables 4-5). This model uses \$CDN 4.40 as the price per kilogram (\$CD N 2.00/lb), which is at the low end of prices charged in O ntario. Also no costs have been at- 
Table 5. A capital budget enterprize analysis for black currant pick-your-own produce, annual cash flows (in C anadian dollars per hectare). ${ }^{z}$

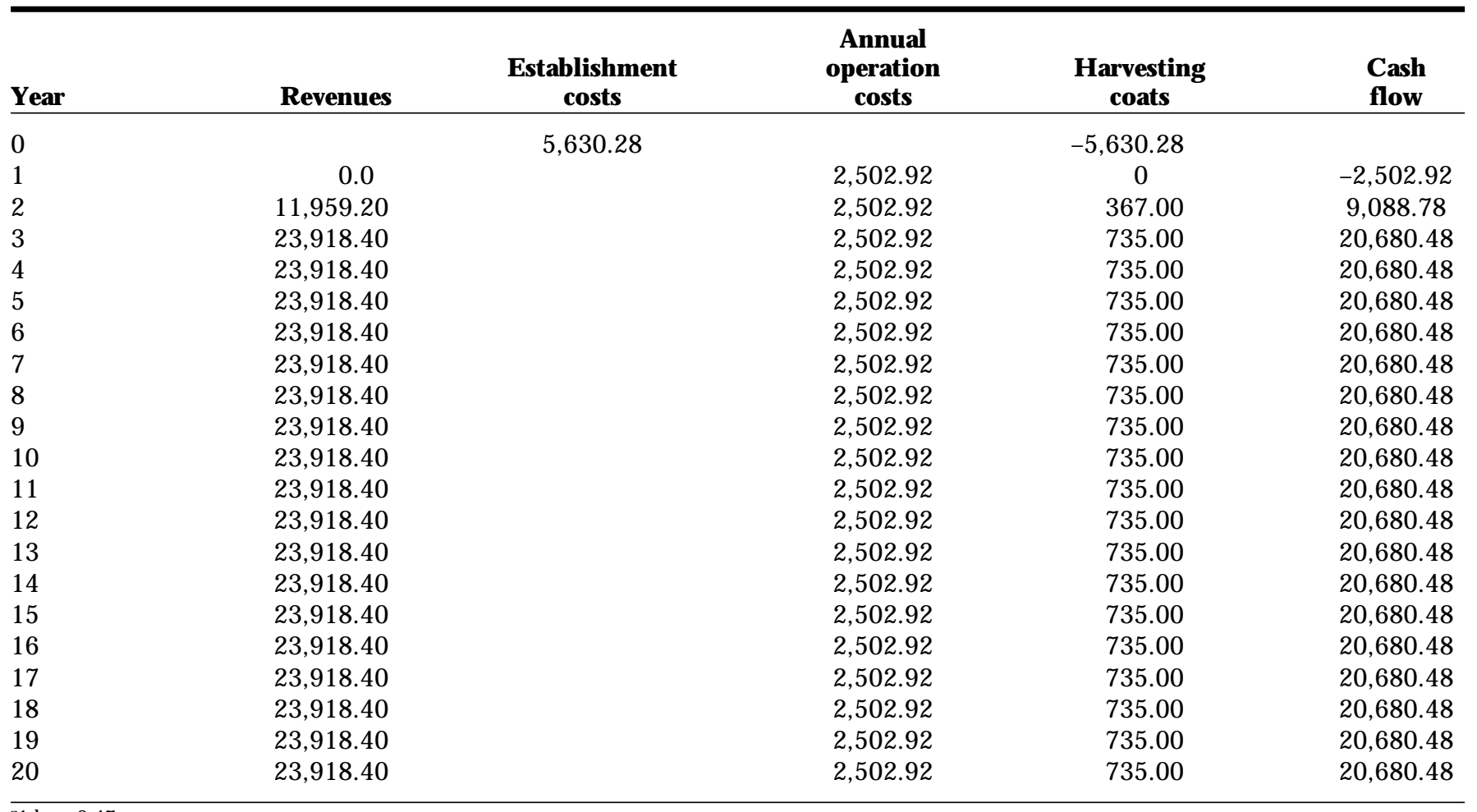

${ }^{\mathrm{z}} 1$ ha $=2.47$ acres

tached to harvesting, although allowance has been made for the labor required to handle customers at a PYO farm.

For the juice market, profitability is closely tied to the world price for black currants. In the spread sheet we have set the price at $\$ C D N \quad 0.85 / \mathrm{kg}$ (\$CDN 0.39/lb) (\$CDN 850/t, $\$ C D N 773$ / ton), which is the price needed to break even (Tables 6-7). Thelargest component in thismodel is the capital cost of a mechanical harvester. The $P$ attenden $C$ hallenger harvester (Ledbury, U nited kingdom) costs UK pounds sterling (UKL) 68,000 , and will harvest 0.5 to $5.0 \mathrm{t}$ ( 0.55 to 5.5 tons) per h. In Europe, contractors charge U KL 100 to 150 / $\mathrm{h}$ to harvest the crop (Pattenden $\mathrm{M}$ achinery L td, personal communication). The recent world price for black currants has fluctuated between \$CD N 450 to $1440 / \mathrm{t}$ (\$CD N 409 to 1309/ ton), which puts the break-even price about in the middle of this range.

Constraints. For a R ibesindustry to develop people need to be aware of several constraints. The most important of these are regulatory controls, diseases, marketing, and price.

Regulatory CONTROL. The availability of new $R$ ibes varieties is con- trolled by importation regulations and by WPBR legislation within several states. Theimportation regulationsfor $\mathrm{R}$ ibes in $\mathrm{C}$ anada and the $\mathrm{U}$ nited States are harmonised. Both countries now prohibit direct entry of $\mathrm{R}$ ibes from other countries. These regulations are designed to prevent reversion, a major endemic disease in Europe, from entering the N orth American continent. $\mathrm{R}$ ibes which can be certified as originating in $\mathrm{C}$ anada and the $\mathrm{U}$ nited States can be imported between the two countries without restrictions. However, entry into both countries requiresaphytosanitarycertificate. The U SD A Animal and Plant $\mathrm{H}$ ealth Inspection Service (APHIS) considers $R$ ibes varieties to be $C$ anadian if they have been grown for at least 1 year in Canada and have been grown under postentry quarantine and can be certified reversion-negative. These regulations have been designed to allow free movement of $\mathrm{R}$ ibes between $\mathrm{C}$ anada and the USA while preventing the introduction of major pest problems.

The effect of these regulations is to slow the introduction of new varieties from the breeding programs in E urope. Presently, there are no breeding programs for Ribes in Canada, although the new European varieties are being tested at several centers. Researchers in M innesota, M aryland, I daho, and $O$ regon have made crosses to combineWPBR immunity with high quality fruit.

Although WPBR restrictions are in effect in 15 states, some states are considering repealing these restrictions. Steve M cKay (2000), presents a summary of the present restrictions.

Diseases. T wo major disease problemsR ibesgrowers must contend with are powdery mildew and WPBR. Powdery mildew, called american gooseberry mildew in Europe, is probably the most significant disease which hampers increases in R ibes acreage. M ost presently grown varieties are susceptible to the disease, and few chemical controlsexist. Consequently, themost effective control is varietal resistance. Fortunately, most new European varieties are resistant to mildew.

WPBR occurs on many currant and gooseberry varieties and leads to defoliation of the leaves early in the fall. This disease is becoming less of a concern in main horticultural regions, as cultivation and forestry practices have eradicated white pines from large parts of these areas. However, this disease still causes major losses in the forest industry. Fortunately now, some 
T able 6. A capital budget enterprise analysis for black currant production for juice, inputs and results (in C anadian dollars per hectcare). ${ }^{z}$

\begin{tabular}{|c|c|c|}
\hline $\begin{array}{l}\text { Q uantity } \\
\text { units }\end{array}$ & $\begin{array}{l}\text { Cost or } \\
\text { price units }\end{array}$ & $\begin{array}{l}\text { Per } \\
\text { unit }\end{array}$ \\
\hline \multicolumn{3}{|l|}{ Inputs } \\
\hline \multicolumn{3}{|l|}{ Establishment } \\
\hline Plants & 5436 plants/ ha & $0.73, \$ /$ plant \\
\hline Planting labor & $20 \mathrm{~h} / \mathrm{ha}$ & $15.00, \$ / \mathrm{h}$ \\
\hline Land preparation & & $247.00, \$ /$ ha \\
\hline Fumigation/ row & & $310.00, \$ /$ ha \\
\hline Black plastic & & $495.00, \$ /$ ha \\
\hline I rrigation equipment & & $310.00, \$ /$ ha \\
\hline \multicolumn{3}{|l|}{ Annual } \\
\hline Fertilizery $(20-20-20)$ & $200 \mathrm{~kg} / \mathrm{ha} /$ year & $2.21, \$ / \mathrm{kg}$ \\
\hline I rrigation & $1000 \mathrm{~kL} / \mathrm{ha} /$ year & $0.264, \$ / \mathrm{kL}$ \\
\hline Pruning labor & $90 \mathrm{~h} / \mathrm{ha} /$ year & $15.00, \$ / \mathrm{h}$ \\
\hline H erbicides (materials plus application) & & $148.0, \$ /$ hal year \\
\hline Insecticides and fungicides ${ }^{x}$ & $0.00, \$ /$ ha/ year & \\
\hline Land & & $247.00, \$ /$ ha/ year \\
\hline \multicolumn{3}{|l|}{$\mathrm{H}$ arvest } \\
\hline Containers (bins) ${ }^{\mathrm{w}}$ & 62 bins/ ha & $100.00, \$ /$ bin \\
\hline $\mathrm{H}$ arvesting machine & 1 & $165,000.00, \$ /$ machine \\
\hline M achine capacity & & 2 , ha/ day \\
\hline & & 20 , days/ year \\
\hline \multicolumn{3}{|l|}{ O utputs and revenue } \\
\hline Yield & $1 \mathrm{~kg} / \mathrm{plant} /$ year & $1.23, \$ / \mathrm{kg}$ \\
\hline \multicolumn{3}{|l|}{ Time related factors } \\
\hline Life expectancy of plants (years) & 20 & \\
\hline Discount rate (\%) & 10.00 & \\
\hline First year production adjustment (\%) & 0.00 & \\
\hline Second year production adjustment (\%) & 50.00 & \\
\hline \multicolumn{3}{|l|}{ Results } \\
\hline Present value of cash flow ( $\$$ / ha) & $\$ 166.47$ & \\
\hline International rate of return (\%) & 10.20 & \\
\hline Budget cost ratio & 1.03 & \\
\hline
\end{tabular}

z1 hectare $=2.47$ acres, $1 \mathrm{~kg}=2.2 \mathrm{lb}, 1 \mathrm{~kL}=264$ gal.

yM inimum composition: $20 \mathrm{~N}-20 \mathrm{P}-20 \mathrm{~K}$.

$\times$ arieties planted are resistant to powdery mildew.

w91.2 $\times 1.2 \times 0.6 \mathrm{~m}(48 \times 48 \times 24$ inch $)$. Assumed half the bins bought in year 2 as only half production harvested, remaining bins purchased in year 3 .

$\mathrm{R}$ ibes cultivars are resistant, and resistant pine seedlings are being selected for reforestation.

In O ntario, we have been actively screening modern european black currant varieties for adaptability in North America. We have selected varietiesthat are mildew resistant and yield consistently. We feel that varieties with these characteristicswill givesufficient benefit to growersto stimulatetheindustry. We have now started on the second stageto identify varieties which are resistant to WPBR. So far we have identified five varieties that have strong resistance to mildew: 'Ben Alder', 'Ben Sarek' and 'Ben Tirran,' 'Polar' and 'T itania' (T able 8). These have given yields of over 30 $\mathrm{t} \cdot \mathrm{ha}^{-1}$ (13 tons/ acre) over a 7-year period and have remained free of powdery mildew. Of these, only 'Polar' and ' $\mathrm{Ti}$ tania' are resistant to WPBR.
Marketing. R ibesproducts which are available throughout $C$ anada, are virtually absent from all parts of the U nited States. A long and concerted marketing effort will be required for them to beaccepted and becomewidely available. Presently, the N orth American public is unaware that $R$ ibesplants or products even exist.

Some marketing efforts are being made, but these are small; either individuals promoting in a small local area, or corporations tied to specific products. Where products are available and promoted people have no problem selling their entire product. This is particularly apparent in areaswith many recent European immigrants. Presently, no commission or grower organizations exist to fund the generic advertising, aloneor with government.

Price. The price of $R$ ibes fruit depends on the end-product. Where fruit is sold PYO or is destined for upmarket products in local areas, the price paid for fruit is largely irrelevant. People will pay a price that gives a grower a profitable return on his investment. H owever, where the fruit is required in large quantities, the world market sets the price. Presently the world market price is depressed and European growers are having difficulty growing their crops profitably.

\section{Conclusions}

Since the legislation to control WPBR was rescinded the cultivation of $\mathrm{R}$ ibes in North America has increased. In C anada and some northern U S states, acreage has been planted for PYO operationsand to producelocally processed products. This acreage is increasing, primarily for the produc- 
Table 7. A capital budget enterprize analysis for black currant production for juice, Annual cash flows (in C anadian dollars per hectcare). ${ }^{z}$

\begin{tabular}{|c|c|c|c|c|c|}
\hline$\underline{\text { Year }}$ & R evenues & $\begin{array}{c}\text { E stablishment } \\
\text { costs }\end{array}$ & $\begin{array}{c}\text { operation } \\
\text { costs }\end{array}$ & $\begin{array}{c}H \text { arvesting } \\
\text { costs }\end{array}$ & $\begin{array}{l}\text { Cash } \\
\text { flow }\end{array}$ \\
\hline 0 & & $5,630.28$ & & & $-5,630.28$ \\
\hline 1 & 0.00 & & $2,504.04$ & 0.00 & $-2,504.04$ \\
\hline 2 & $2,310.30$ & & $2,504.04$ & $4,813.64$ & $-5,007.38$ \\
\hline 3 & $4,620.60$ & & $2,504.04$ & 813.64 & $1,302.92$ \\
\hline 4 & $4,620.60$ & & $2,504.04$ & 250.00 & I,866.56 \\
\hline 5 & $4,620.60$ & & $2,504.04$ & 250.00 & I,866.56 \\
\hline 6 & $4,620.60$ & & $2,504.04$ & 250.00 & I,866.56 \\
\hline 7 & $4,620.60$ & & $2,504.04$ & 250.00 & I,866.56 \\
\hline 8 & $4,620.60$ & & $2,504.04$ & 250.00 & I,866.56 \\
\hline 9 & $4,620.60$ & & $2,504.04$ & 250.00 & I,866.56 \\
\hline 10 & $4,620.60$ & & $2,504.04$ & 250.00 & I,866.56 \\
\hline 11 & $4,620.60$ & & $2,504.04$ & 250.00 & I,866.56 \\
\hline 12 & $4,620.60$ & & $2,504.04$ & 250.00 & I,866.56 \\
\hline 13 & $4,620.60$ & & $2,504.04$ & 250.00 & I,866.56 \\
\hline 14 & $4,620.60$ & & $2,504.04$ & 250.00 & I,866.56 \\
\hline 15 & $4,620.60$ & & $2,504.04$ & 250.00 & $1,866.56$ \\
\hline 16 & $4,620.60$ & & $2,504.04$ & 250.00 & I,866.56 \\
\hline 17 & $4,620.60$ & & $2,504.04$ & 250.00 & $1,866.56$ \\
\hline 18 & $4,620.60$ & & $2,504.04$ & 250.00 & I,866.56 \\
\hline 19 & $4,620.60$ & & $2,504.04$ & 250.00 & I,866.56 \\
\hline 20 & $4,620.60$ & & $2,504.04$ & 250.00 & I,866.56 \\
\hline
\end{tabular}

${ }^{\mathrm{z} 1 \mathrm{ha}}=2.47$ acres.

Table 8. C haracteristics and availability of selected black currant varieties suitable for production in 0 ntario.

\begin{tabular}{|c|c|c|c|c|c|c|}
\hline$\underline{\text { Cultivar }}$ & $\begin{array}{l}\text { Berry } \\
\text { size }^{2} \\
\end{array}$ & $\begin{array}{l}\text { Powdery } \\
\text { mildew } \\
\text { resistance } \\
\end{array}$ & $\begin{array}{l}\text { WPBR } \\
\text { resistance } \\
\end{array}$ & $\begin{array}{l}\text { Plant } \\
\text { habit }\end{array}$ & M arket & Availability \\
\hline Ben Alder & M edium & Resistant & Very susceptible & M oderately vigorous & Juice & $\begin{array}{l}\text { Available, derived from virus- } \\
\text { tested material }\end{array}$ \\
\hline Ben Connan & Large & Resistant & M oderately resistant & Semidwarf & D essert & N ot available \\
\hline Ben Sarek & Large & Resistant & M oderately resistant & Semidwarf & D essert & $\begin{array}{l}\text { Available, derived from virus- } \\
\text { tested material }\end{array}$ \\
\hline Ben Tirran & M edium & Resistant & Very susceptible & M oderately vigorous & Juice & Not available \\
\hline Polar & Large & Resistant & Resistant & $\begin{array}{l}\text { M oderately vigorous, } \\
\text { spreading }\end{array}$ & D essert & Not available \\
\hline Titania & Large & Resistant & Resistant & Extremely vigorous & D essert/ juice & Available \\
\hline D 16/ 8/ 14 & M edium & Resistant & Resistant & M oderately vigorous & Not known & For trial \\
\hline $\mathrm{F} 4 / 1 / 67$ & $\begin{array}{l}\text { Large } \\
\text { D warf }\end{array}$ & Resistant & M oderately resistant & Semidwarf & Not known & For trial \\
\hline$C 2 / 2 / 1$ & M edium & Resistant & M oderately resistant & Semidwarf & Not known & For trial \\
\hline
\end{tabular}

zM edium $=0.7-0.9 \mathrm{~g}(0.025-0.032 \mathrm{oz}$.$) per berry, large =>0.9 \mathrm{~g}(0.032 \mathrm{oz}$.$) per berry.$

xWPBR = white pine blister rust.

tion of black currants.

The factors that will govern the rate at which this acreage increases will be purely economic: what are the markets and can a profit be made. WPBR in $\mathrm{R}$ ibes is a relatively minor horticultural problem that will either be ig- nored or dealt with by using resistant varieties.

The acreage of $R$ ibeswill increase initially in PYO operations. Surplus fruit from these operations will find its way into the local farm markets and into local processing. These opera- tions have the potential to be very profitable, but the total acreage throughout North America will be relatively small.

For R ibesto becomeamajor crop, farmers will need to plant large acreages for juice and associated products. 
When or whether large acreages will come into existencewill depend on the world pricefor $\mathrm{R}$ ibes, particularly black currants, the existence of markets for the product, the cost of mechanical harvesting, and competition from Europe. However, if these constraints can be overcome, $\mathrm{N}$ orth America has the potential for up to 40,000 ha (100,000 acres).

\section{Literature cited}

Andrews, D. 1999. Blackcurrant growers bid to calm market. Grower (U K) 131(25):6.

Barney, D.L. 1996. Ribes production in N orth America: Past, present, and future. H ortScience 31:774-776.

Bauer, A. 1986. N ew results of breeding $\mathrm{R}$ ibesnidigrolaria: Amphiploid species hybrids between blackcurrant and gooseberry. Acta H ort. 183:107-110.

Brennan, R.M . 1996. Currants and Gooseberries, p. 191-295. In: J. Janick and J.N . M oore (eds.). Fruit breeding. vol. 2. Vine and small fruits. Wiley, N ew York.

Environment Canada. 1982. Canadian climate normals. vol. 4. Degree days 19511980. Supply and Services Canada, Ottawa.

Food and Agricultural O rganization. 1999. World production of currants and gooseberries 1996-1998. 31 Aug. 1999. «ttp:/ / apps.fao.org / in 500/ nph-wrap.pl?>

H armat, L., A. Porpaczy, D.G. H imelrick, and G.J. G alletta. 1990. Currant and goose- berry management, p. 245-272. In: G.J. Galletta and D.G. H imelrick (eds.). Small fruit management. Prentice $\mathrm{H}$ all, Englewood Cliffs, N.J.

H imelrick, D.J. and G. J. Galletta. 1990. Factors that influence small fruit management, p. 14-82. In: G.J. Galletta and D.G. $\mathrm{H}$ imelrick (eds.). Small fruit management. Prentice $\mathrm{H}$ all, Englewood Cliffs, N.J.

Industry Canada. 1999. Canadian industry statistics. Industry overview. SI C-E 1031 Canned and preserved fruit and vegetable industry. II. Industry definition. 3 Sept. 1999. <http:/ / strategis.ic.gc.ca/ ssq/ i01031ze.html>.

Keep, E. 1975. Currants and gooseberries, p. 197-268. In: J. Janick and J.N. Moore (eds.). Advances in fruit breeding. Purdue U niv. Press, West LaFayette, Ind.

M cKay, S. 2000. State regulation of $\mathrm{R}$ ibes to control white pine blister rust. HortTechnology 10(3):562-564.

Rehder, A. 1937. M anual of cultivated trees and shrubs. M acmillan, N ew York.

Soper, J.H . and M.L. H eimberger. 1982. Shrubs of O ntario. Roy. O nt. M useum, Toronto.

Swartz, H .J. and S.E. Gray. 1981. Annual chill unit accumulation in the U.S. Fruit Var. J. 35:80-83.

U.S. Department of Agriculture. 1982. Composition of foods: Fruitsand fruitjuices raw, processed and prepared. USDA H Uman N utr. I nfo. Serv., Agr. H dbk. 8-9.U .S. Govt. Printing O ffices, Wash., D.C. 